\title{
COMPETITIVIDADE DAS EXPORTAÇÕES BRASILEIRAS E COLOMBIANAS DE CAFÉ $^{1}$
}

\section{COMPETITIVENESS OF BRAZILIAN AND COLOMBIAN EXPORTS OF COFFEE}

Leonardo Sangoi Copetti ${ }^{2}$

Daniel Arruda Coronel ${ }^{3}$

\section{RESUMO}

O objetivo deste estudo foi o de analisar a competitividade das exportações brasileiras no mercado mundial do café, entre 2000 a 2018, em comparação ao terceiro produtor e exportador mundial, a Colômbia. Os dados foram coletados no site do USDA (United States Department of Agriculture), do UN COMTRADE (United Nations Comtrade), da FAO (Food and Agriculture Organization of the United Nations) e da WTO (World Trade Organization). A metodologia empregada baseou-se no Índice de Vantagem Comparativa Revelada Simétrica (VCRS), na Razão de Concentração (CR), e no Índice de Orientação Regional (IOR). Os resultados revelaram que tanto o Brasil quanto a Colômbia apresentaram vantagens comparativas para o café. Em relação à CR, o Brasil apresentou concentração e a Colômbia, desconcentração das exportações. O IOR indicou orientação das exportações de café do Brasil à Alemanha, à Itália, e aos Estados Unidos. Já o IOR da Colômbia apresentou orientação das exportações de café aos Estados Unidos, à Alemanha e ao Japão.

Palavras-Chave: Café. Competitividade. Exportações. Comércio Internacional.

\begin{abstract}
The objective of this study was to analyze the competitiveness of Brazilian exports in the world coffee market, from 2000 to 2018, in comparison to the third world producer and exporter, Colombia. The data were collected in the USDA (United States Department of Agriculture), UN COMTRADE (United Nations Comtrade), FAO (Food and Agriculture Organization of the United Nations) and WTO (World Trade Organization) sites. The methodology used was based on the Revealed Symmetric Comparative Advantage Index (RSCA), Concentration Ratio (CR), and on the Regional Orientation Index (ROI). The results revealed that both Brazil and Colombia presented comparative advantages for coffee. In relation to $\mathrm{CR}$, Brazil presented concentration and Colombia deconcentration of exports. The ROI indicated orientation of

\footnotetext{
${ }^{1}$ Este artigo faz parte de uma pesquisa a qual visa estudar a competitividade das exportações brasileiras no mercado do café e conta com o apoio do CNPq, através da chamada Universal-2018.

${ }^{2}$ Mestre em Administração pela Universidade Federal de Santa Maria (UFSM). Rio Grande do Sul. Brasil. Email: leonardocopetti@hotmail.com ORCID: https://orcid.org/0000-0002-4801-4714.

${ }^{3}$ Doutor em Economia Aplicada pela Universidade Federal de Viçosa (UFV). Universidade Federal de Santa Maria. Rio Grande do Sul. Brasil. E-mail: daniel.coronel@uol.com.br. ORCID: https://orcid.org/0000-00030264-6502
}

DRd - Desenvolvimento Regional em debate (ISSNe 2237-9029)

v. 9, p. 646-667, 2019. 
coffee exports from Brazil to Germany, Italy and the United States. Yet, the ROI of Colombia presented orientation from coffee exports to the United States, Germany and Japan.

Keywords: Coffee. Competitiveness. Exports. International trade.

Como citar este artigo: COPETTI, L. S.; CORONEL, D. A. Competitividade das exportações brasileiras e colombianas de café. DRd - Desenvolvimento Regional em debate, v. 9, p. 646667, 28 out. 2019. DOI: https://doi.org/10.24302/drd.v9i0.2218

Artigo recebido em: 29/07/2019

Artigo aprovado em: 27/09/2019

Artigo publicado em: 29/10/2019

\section{INTRODUÇÃO}

O comércio mundial cresceu $223 \%$ em exportações ligadas ao agronegócio, entre os anos de 2000 a 2018, passando de US\$ 558 bilhões a US\$ 1,80 trilhões, respectivamente, segundo a World Trade Organization (WTO, 2019). Além disso, a participação do setor sobre o total exportado mundial manteve-se em 9\%. Segundo Vieira Filho e Fishow (2017), esse período, a partir da década de 2000, foi caracterizado como o "boom das commodities", sendo impulsionado pelo acelerado volume de exportações agropecuárias mundiais e influenciadas pela alta demanda dos produtos de origem primária nos países emergentes, com a modernização tecnológica e a concorrência entre os países exportadores no mundo (VIEIRA FILHO; FISHLOW, 2017).

Neste contexto, segundo a World Trade Organization (WTO, 2019), o Brasil teve um incremento de quase $500 \%$ no faturamento das exportações ligadas ao agronegócio que, nos anos 2000, eram de US\$15,5 bilhões e passaram para US\$ 93 bilhões em 2018. Já a participação do setor sobre o total exportado pelo país teve aumento de 10,71 pontos percentuais, sendo que, em 2000, era de 28,06\% e, em 2018, de 38,77\%. Além disso, conforme dados da Food and Agriculture Organization of the United Nations - (FAO, 2019), o Brasil representa o maior exportador mundial de café, visto que, em 2018, o valor exportado foi de US\$ 4,36 bilhões, o que representou 1,95\% das exportações deste país, e $23 \%$ das exportações mundiais. Em comparação com ano 2000, o crescimento das exportações brasileiras de café foi de $179 \%$, e, neste ano, eram de US\$ 1,56 bilhões.

Já na Colômbia, a participação do agronegócio no total exportado reduziu cerca de $2 \%$, de 2000 a 2018, mas houve incremento no faturamento das exportações ligadas ao setor de $123 \%$, sendo que, em 2000, era de US\$ 3,11 bilhões, saltando para US\$ 6,95 bilhões em 2018 (WTO, 2019). O crescimento nas exportações de café neste período foi de $112 \%$, passando de US\$ 1,07 bilhões nos anos 2000 para US\$ 2,27 bilhões em 2018, representando 5,40\% das exportações do país e 12\% das exportações mundiais (UN COMTRADE, 2019).

Neste cenário, o presente estudo tem o seguinte problema de pesquisa: "Brasil e Colômbia foram competitivos no mercado mundial do café entre 2000 a 2018 ?" Para responder ao questionamento, o objetivo do trabalho foi o de analisar a competitividade das exportações

DRd - Desenvolvimento Regional em debate (ISSNe 2237-9029) 
brasileiras e colombianas no mercado mundial do café, entre 2000 a 2018, uma vez que o Brasil é o maior produtor e exportador, e a Colômbia é a terceira maior produtora e exportadora de café mundial.

A metodologia empregada na pesquisa baseou-se no Índice de Vantagem Comparativa Revelada Simétrica (VCRS), na Razão de Concentração (CR), e no Índice de Orientação Regional (IOR). O ineditismo desta pesquisa está relacionado à análise do mercado do café internacional, traçando um comparativo entre Brasil e Colômbia que, juntos, destinaram ao mercado externo mais de US\$ 6,63 bilhões em 2018 de café verde, representando $35 \%$ do faturamento total mundial na exportação desta commodity (UN COMTRADE, 2019). Além disso, as exportações do café verde representam uma parcela do comércio mundial de café, correspondente a $61 \%$, que também é composto por produtos tais como os extratos de café e o café torrado, que, em conjunto com o café verde, totalizaram mais de US\$ 31,08 bilhões em exportação em 2018 (FAO, 2019). Desta forma, esta pesquisa pode servir de subsídio para ações visando fomentar a competitividade do setor, como esforço de liberalização multilateral que exclua a redução de barreiras comerciais no agronegócio entre os países, participação de acordos preferenciais de comércio e políticas setoriais de apoio à agricultura (GURGEL, 2014).

Com o intuito de atingir o objetivo do trabalho de analisar a competitividade das exportações brasileiras no mercado mundial do café, entre 2000 a 2018, em comparação com a Colômbia, este estudo está organizado em mais quatro seções, além desta introdução. $\mathrm{Na}$ segunda seção, apresentam-se o conceito de competitividade e os estudos empíricos realizados sobre a exportação e a competitividade do café brasileiro, o panorama do comércio internacional do café, destacando o Brasil e a Colômbia. A terceira seção compreende os procedimentos metodológicos. Na quarta seção, os resultados são discutidos e analisados. Por fim, na quinta seção, são expostas as conclusões do estudo.

\section{COMPETITIVIDADE NO MERCADO MUNDIAL DO CAFÉ}

\subsection{COMPETITIVIDADE}

A competitividade, segundo Ricardo (1996), economista inglês do século XIX, relaciona-se às Vantagens Comparativas que um país possui em relação a outro, pela qual a abundância de recursos naturais favoreceria o competidor que os tivesse. Também se refere a outros fatores como a escala de produção, a existência de capital físico (equipamentos, infraestrutura, vias, portos, etc.) e humano (investimentos destinados à formação educacional e profissional de uma determinada população), e abertura econômica.

Ricardo (1996) explica a teoria utilizando como referência Inglaterra e Portugal e os produtos tecidos e vinhos. Se Portugal ou Inglaterra não tivessem nenhuma ligação comercial entre si e produzissem os dois produtos, seriam obrigados a aplicar todos os seus recursos na produção destes e, com isso, os resultados seriam provavelmente inferiores em quantidade e qualidade. Já o comércio faria com que os países se beneficiassem com a especialização e produção do produto em que possuem maior vantagem e com a importação do outro.

DRd - Desenvolvimento Regional em debate (ISSNe 2237-9029) 
No exemplo citado por Ricardo (1996), a Inglaterra produziria tecidos e vinhos utilizando, respectivamente, 100 e 120 homens por ano e Portugal 90 e 80 . Da situação analisada no todo se deduziria que a produção deveria ocorrer exclusivamente em Portugal, já que o custo na produção de ambos os produtos é menor, contudo, examinando o cenário à luz das vantagens comparativas, percebe-se que, se a Inglaterra se especializasse em tecidos e Portugal em vinhos, ambos obteriam maiores ganhos na produção e na troca comercial. Neste caso, o preço relativo de cada produto seria de $0,83(100 / 120)$ para o tecido na Inglaterra; 1,20 (120/100) para o vinho na Inglaterra; 1,125 (90/80) para o tecido em Portugal; e 0,88 (80/90) para o vinho em Portugal. Ou seja, o aperfeiçoamento na produção do produto em que cada país possui maior vantagem comparativa e a troca pelo outro proporcionaria maiores ganhos para ambos.

Por outro lado, segundo Porter (1988), a competitividade também estaria relacionada à produtividade que determinado país possui no processo de fabricação de um produto, que, para Ricardo, era explicada pelos custos de produção e pela vantagem comparativa. Tendo em vista este posicionamento, é possível elucidar o porquê de certos países como a Alemanha, a Suíça e a Suécia, onde os salários são altos e a mão de obra não é tão abundante, prosperem e serem altamente competitivos.

Ainda, segundo Porter (1988), a vantagem competitiva de uma nação relaciona-se a quatro determinantes, a saber:

1. condições de fatores: a posição do país nos fatores de produção, como trabalho especializado, infraestrutura, necessários à competição em determinada indústria;

2. condições de demanda: como a demanda interna de um país se manifesta voltada aos produtos ou serviços da indústria, este determinante é relevante na medida em que promove a melhoria e inovação pelas empresas do país e reflete o grau de exigência que o mercado tem pela qualidade dos produtos;

3. indústrias correlatas e de apoio: referem-se às indústrias produtoras do maquinário necessário à produção de determinado produto; e

4. estratégia, estrutura e concorrência das empresas: as condições e políticas da nação onde se está produzindo determinado produto. O autor cita o caso de Londres, na Inglaterra, que tem seu desenvolvimento balizado na demanda avançada de muitos bens e serviços, na concentração industrial e na presença maciça de mão de obra altamente especializada.

Para Best (1990), uma organização de negócios é competitiva quando integra o pensar e o fazer através da procura continuada de melhoria. Como forma de elucidar essa questão, o autor cita o exemplo de duas regiões produtoras de armas leves para infantaria, uma em Birmingham, na Inglaterra, e outra nos Estados Unidos, em Conecticut, chamada de Springfield Armory. Nos Estados Unidos, a produção era bem desenvolvida, com sistemas automatizados em torno e forja. Já na Inglaterra, o processo produtivo se dava de forma manual e artesanal. Como resultado, a indústria americana desenvolveu-se e tornou-se produtiva, e a inglesa tornouse decadente e entrou em um processo de recessão.

Ainda nesta perspectiva, Best (1990) conclui que a mudança nos sistemas de produção relaciona-se às grandes mudanças tecnológicas ocorridas nos Estados Unidos, que 
possibilitaram a introdução de novas tecnologias de produção e, consequentemente, promoveram seu desenvolvimento e prosperidade.

Além disso, a definição do conceito de competitividade relaciona-se diretamente à escolha dos indicadores de desempenho a serem utilizados. Como exemplo, cita-se a evolução da participação de mercado, que pode sintetizar muito fatores competitivos de um concorrente (KENNEDY et al., 1998).

Fatores como custos, produtividade, inovação em produto e processo também são frequentemente utilizados como forma de comparar e medir a competitividade. Esses fatores, se somados, apresentam-se como determinantes da preservação e melhoria das participações de mercado (KENNEDY et al., 1998).

É importante ressaltar que a evolução da participação de mercado refere-se a um fator no passado, associado às vantagens competitivas já adquiridas. Também se relaciona à adequação da empresa ou nação no setor que esteja concorrendo (KENNEDY et al., 1998).

Nesta subseção, foram apresentados conceitos sobre a competitividade que embasaram a presente pesquisa. Na subseção seguinte, apresentam-se estudos empíricos sobre a competitividade brasileira no mercado do café.

\subsection{ESTUDOS EMPÍRICOS ACERCA DAS EXPORTAÇÕES E DA COMPETITIVIDADE BRASILEIRA NA COMERCIALIZAÇÃO DO CAFÉ}

Sereia, Camara e Anhesini (2012) analisaram o comportamento de indicadores de comércio exterior do complexo cafeeiro brasileiro entre 1990 e 2007. Para tanto, foram utilizados o modelo Constant Market Share (CMS) com os produtos café verde, café solúvel, café torrado e bebidas com café, bem como o índice de Vantagem Comparativa Revelada Simétrica (VCRS). A aplicação do modelo CMS permitiu analisar a decomposição e a contribuição das fontes de crescimento das exportações do café em três períodos considerados: período I (1990-1993 no comparativo com 1994-1998); período II (1994-1998 no comparativo com 1999-2003); e período III (1999-2003 no comparativo com 2004-2007). O modelo CMS permitiu identificar quatro determinantes, a saber: a) o efeito crescimento do comércio internacional; b) o efeito composição da pauta de exportações; c) o efeito destino das exportações; e d) o efeito competitividade, determinado pelo resíduo das demais. Como resultados do modelo CMS, na análise dos quatro produtos em conjunto (café verde, solúvel, torrado e bebidas com café), tem-se que o desempenho das exportações brasileiras é atribuído aos efeitos de crescimento do comércio mundial e, principalmente, da competitividade, que apresentou resultados positivos durante todo período, oscilando entre $51,1 \%$ a $222,2 \%$. O mesmo resultado do CMS ocorreu na análise dos produtos do café em separado, sendo o desempenho nas exportações relacionado aos efeitos crescimento mundial e ao efeito competitividade que variou, para o café verde, o café solúvel, o café torrado e as bebidas com café, respectivamente, de $51,1 \%$ a $226,2 \%$, de $38,3 \%$ a $178,3 \%$, de $56,6 \%$ a $122,9 \%$, e de $54,8 \%$ a 149,2\%. Para o VCRS, as exportações brasileiras de café apresentam-se competitivas com índice variando, para os produtos café verde e café solúvel, respectivamente, de 0,89 a 0,93, e 
de 0,81 a 0,92 . O produto café torrado não se apresentou competitivo durante o período de análise.

Thomé e Ferreira (2015) realizaram pesquisa sobre a competitividade das exportações do café brasileiro no comparativo com seus principais concorrentes (Vietnã, Alemanha, Colômbia, Suíça, Honduras, Itália, Indonésia, Bélgica e Etiópia), no período de 2003 a 2012, e para tanto, utilizaram a seguinte metodologia: índices de Vantagem Comparativa Revelada (IVCR), Posição Relativa do Mercado (PRM), Índice de Herfindahl-Hirschman (IHH) para avaliar a concentração de mercado, e Índice de Exportação Líquida (NEI). Como resultados, o Brasil apresentou-se competitivo durante todo período de análise, com VCRs superiores à unidade, e com valores passando de 17,74 em 2003 a 12,73 em 2012, e chegando, em 2004, a 18,03. Em relação à PRM, o Brasil apresentou como resultado o valor de 8,57 em 2012, conferindo-lhe destaque no comércio internacional do café, seguido por Colômbia $(5,15)$ e Vietnã $(2,68)$. Já em relação ao $\mathrm{IHH}$, apresentou como resultado mercado concentrado nas exportações mundiais de café, com valores passando de 42,62\%, em 2003, a 41,05\% em 2012. O NEI revelou o perfil dos países exportadores: Itália e Bélgica, com valor do índice próximo a zero, região de neutralidade, indicando que estes países não apresentam características de produção doméstica, mas são estáveis em comércio (importação e exportação); Brasil, Vietnã, Colômbia, Honduras, Indonésia e Etiópia com valores próximos a 1, indicando estabilidade na exportação com base na produção doméstica; e Alemanha e Suíça, com valores negativos e não próximos a zero e a -1, revelando a estabilidade na comercialização (importação e exportação), e com acentuado consumo doméstico.

Franck et al. (2016) investigaram a competitividade das exportações brasileiras de café utilizando os Índices de Orientação Regional (IOR) e de Vantagem Comparativa Revelada (IVCR), no período de 1999 a 2014. Os resultados indicaram que as exportações brasileiras de café foram orientadas durante todo período para a Alemanha, com IOR superior à unidade, e orientadas aos Estados Unidos somente a partir do ano de 2006. Em ambos os países, a tendência do IOR foi crescente, o que indica incremento das exportações do Brasil aos parceiros comerciais. Em relação ao IVCR, foi superior à unidade de 1999 a 2014, e com tendência decrescente, indicando a competitividade do país brasileiro no comércio mundial do café, e também redução desta no período de análise.

Arevalo, Arruda e Carvalho (2016) utilizaram o modelo Constant Market Share (CMS) e o Índice de Vantagem Comparativa Revelada (IVCR) para analisar as exportações totais de café verde do Brasil, Colômbia e Peru, no período de 1994 a 2013. A aplicação do modelo CMS permitiu analisar a decomposição e a contribuição das fontes de crescimento das exportações do café em três períodos considerados: período I (1994-1998 no comparativo com 1999-2003); período II (1999-2003 no comparativo com 2004-2008); e período III (2004-2008 no comparativo com 2009-2013). O modelo CMS permitiu identificar três efeitos: a) crescimento das exportações no mundo; b) composição da pauta de exportações do país; e c) resíduo inexplicável ou "efeito competitividade". Como resultados, as exportações brasileiras de café foram competitivas durante todo o período de análise, com IVCR superior à unidade, variando entre 7,20 e 20,84. Além disso, o Brasil foi o mais competitivo em 1999, 2001, e de 2004 a 2011, apresentando IVCRs superiores aos concorrentes. Em relação ao CMS, o Brasil ampliou seu market-share nos períodos I, II, e II, respectivamente, de $18,73 \%$ para $21,74 \%$, de $21,74 \%$ para $25,13 \%$, de $25,13 \%$ para $28,61 \%$, sendo que o efeito crescimento do mercado mundial foi determinante para explicar o incremento nas exportações de café do Brasil, dado que o valor percentual nos três períodos foi muito significativo. $\mathrm{O}$ efeito competitividade apresentou-se

DRd - Desenvolvimento Regional em debate (ISSNe 2237-9029) 
positivo nos períodos II e III, explicando parte do crescimento nas exportações brasileiras do café verde.

Na Figura 1, faz-se uma síntese dos estudos acerca da competitividade do café.

Figura 1 - Síntese dos estudos empíricos

\begin{tabular}{|c|c|c|c|c|c|}
\hline Autores & Região & Período & Produtos & Metodologia & Resultados \\
\hline $\begin{array}{c}\text { Sereia, } \\
\text { Camara \& } \\
\text { Anhesini } \\
(2012)\end{array}$ & Brasil & $\begin{array}{l}1990- \\
2007\end{array}$ & $\begin{array}{c}\text { Café (verde, } \\
\text { solúvel e } \\
\text { torrado) }\end{array}$ & CMS e VCRS. & $\begin{array}{l}\text { Brasil competitivo } \\
\text { no café verde e } \\
\text { solúvel de } 1990 \text { a } \\
2007 .\end{array}$ \\
\hline $\begin{array}{c}\text { Thomé \& } \\
\text { Ferreira } \\
(2015)\end{array}$ & $\begin{array}{c}\text { Brasil, Vietnã, } \\
\text { Alemanha, } \\
\text { Colômbia, Suíça, } \\
\text { Honduras, Itália, } \\
\text { Indonésia, Bélgica e } \\
\text { Etiópia }\end{array}$ & $\begin{array}{l}2003- \\
2012\end{array}$ & Café & $\begin{array}{l}\text { IVCR, PRM, } \\
\text { IHH, e NEI. }\end{array}$ & $\begin{array}{l}\text { Brasil competitivo } \\
\text { de } 2003 \text { a } 2012 .\end{array}$ \\
\hline $\begin{array}{c}\text { Franck et al. } \\
(2016)\end{array}$ & Brasil & $\begin{array}{l}1999- \\
2014\end{array}$ & Café & IOR e IVCR. & $\begin{array}{c}\text { Brasil competitivo } \\
\text { de } 1999 \text { a } 2014 .\end{array}$ \\
\hline $\begin{array}{c}\text { Arevalo, } \\
\text { Arruda \& } \\
\text { Carvalho } \\
(2016)\end{array}$ & $\begin{array}{l}\text { Brasil, Colômbia e } \\
\text { Peru }\end{array}$ & $\begin{array}{l}1994- \\
2013\end{array}$ & Café verde & CMS e IVCR. & $\begin{array}{c}\text { Brasil competitivo } \\
\text { de } 1994 \text { a } 2013 .\end{array}$ \\
\hline
\end{tabular}

Fonte: Organização dos autores (2019)

Nesta subseção, foram reunidos estudos realizados sobre o café brasileiro a fim de analisar as exportações e a competitividade do país na comercialização do produto, com base, principalmente, no IVCR e VCRS. Os estudos supracitados revelaram que o Brasil apresentou competitividade nas exportações de café de 1990 a 2014. Na subseção seguinte, apresenta-se o panorama do comércio internacional do café, com destaque para o Brasil e a Colômbia.

\subsection{PARTICIPAÇÃO DO BRASIL E DA COLÔMBIA NO MERCADO DO CAFÉ}

Segundo o United States Department of Agriculture (USDA, 2019a), o Brasil foi o maior produtor e exportador mundial de café, na safra de 2018/2019, quando o país produziu 3,89 milhões de toneladas do produto, representando $37,13 \%$ da produção mundial, que foi de 10,47 milhões de toneladas. Neste período, a Colômbia aparece em terceiro lugar, com a produção de 0,86 milhões de toneladas. Do total produzido pelo mundo, cerca de 8,28 milhões de toneladas foram destinadas à exportação: o Brasil destinou 2,38 milhões de toneladas ao mercado externo, assumindo a primeira posição entre os maiores exportadores mundiais, e a Colômbia exportou 0,80 milhões de toneladas, sendo a terceira maior exportadora. A Tabela 1 ilustra as participações dos maiores produtores de café nas safras de 2000/2001 e 2018/2019.

DRd - Desenvolvimento Regional em debate (ISSNe 2237-9029) 
Tabela 1 - Participação dos maiores produtores mundiais de café nas safras de 2000/2001 e 2018/2019

\begin{tabular}{|c|c|c|c|c|c|}
\hline \multirow[b]{2}{*}{ Pais } & \multicolumn{2}{|c|}{$2000 / 2001$} & \multicolumn{2}{|c|}{$2018 / 2019$} & \multirow[b]{2}{*}{$\begin{array}{l}\text { Variação da } \\
\text { participação } \\
\text { (em p.p.) }\end{array}$} \\
\hline & $\begin{array}{l}\text { Produção } \\
\text { (milhões de } \\
\text { toneladas) }\end{array}$ & $\begin{array}{c}\text { Participação } \\
(\%)\end{array}$ & $\begin{array}{l}\text { Produção } \\
\text { (milhões de } \\
\text { toneladas) }\end{array}$ & $\begin{array}{c}\text { Participação } \\
(\%)\end{array}$ & \\
\hline B rasil & 2,05 & 29,09 & 3,89 & 37,13 & 8,04 \\
\hline Vietnã & 0,92 & 13,08 & 1,82 & 17,42 & 4,34 \\
\hline Colômbia & 0,63 & 8,96 & 0,86 & 8,19 & $-0,76$ \\
\hline Ind onésia & 0,39 & 5,54 & 0,64 & 6,07 & 0,53 \\
\hline Etiópia & 0,17 & 2,36 & 0,44 & 4,15 & 1,79 \\
\hline Honduras & 0,17 & 2,41 & 0,42 & 4,01 & 1,60 \\
\hline India & 0,30 & 4,28 & 0,31 & 2,96 & $-1,32$ \\
\hline Ug and a & 0,19 & 2,64 & 0,29 & 2,75 & 0,11 \\
\hline Perv & 0,17 & 2,41 & 0,26 & 2,51 & 0,10 \\
\hline México & 0,29 & 4,09 & 0,24 & 2,32 & $-1,77$ \\
\hline $\mathrm{R}$ esto do $\mathrm{M}$ undo & 1,77 & 25,13 & 1,31 & 12,46 & $-12,67$ \\
\hline Total & 7,03 & 100,00 & 10,47 & 100,00 & - \\
\hline
\end{tabular}

Fonte: Elaborado pelos autores a partir de USDA (2019)

Nota: Ranking relacionado ao ano de 2018

Com base na Tabela 1, percebe-se que o incremento na produção de café no mundo, nos anos de 2000 a 2018 , foi de $48,93 \%$, passando de 7,03 para 10,47 milhões toneladas. O Brasil e a Colômbia tiveram um aumento de $89,76 \%$ e $36,51 \%$ respectivamente. No quesito participação de mercado, esses países apresentaram tendências opostas, de crescimento de $8,04 \%$ para o Brasil e redução de $0,76 \%$ para a Colômbia. Outros países que elevaram sua participação de mercado foram Vietnã (4,34\%), Indonésia (0,53\%), Etiópia (1,79\%), Honduras $(1,60 \%)$, Uganda $(0,11 \%)$ e Peru $(0,10 \%)$. Por outro lado, o país que mais reduziu sua participação de mercado foi o México, em 1,77\%, correspondendo a um declínio na produção de $22,83 \%$, que passou de 0,29 milhões de toneladas na safra de 2000/2001 a 0,24 milhões de toneladas na safra de 2018/2019, fato ligado à epidemia de ferrugem nas plantações em 2012, quando $20 \%$ das plantações foram perdidas em função da doença (USDA, 2019b).

A seguir, na Tabela 2, é avaliada a participação dos principais exportadores mundiais de café com base nos mesmos períodos.

Tabela 2 - Participação dos maiores exportadores mundiais de café verde nas safras de 2000/2001 e 2018/2019

\begin{tabular}{|c|c|c|c|c|c|}
\hline \multirow[b]{2}{*}{ Pais } & \multicolumn{2}{|c|}{$2000 / 2001$} & \multicolumn{2}{|c|}{$2018 / 2019$} & \multirow[b]{2}{*}{$\begin{array}{l}\text { Variação da } \\
\text { participação } \\
\text { (em p.p.) }\end{array}$} \\
\hline & $\begin{array}{l}\text { Exportação } \\
\text { (milhöes de } \\
\text { toneladas) }\end{array}$ & $\begin{array}{c}\text { Participação } \\
(\%)\end{array}$ & $\begin{array}{l}\text { Exportação } \\
\text { (milhões de } \\
\text { toneladas) }\end{array}$ & $\begin{array}{c}\text { Participação } \\
(\%)\end{array}$ & \\
\hline Brasil & 1,18 & 21,66 & 2,38 & 28,80 & 7,14 \\
\hline Vietnã & 0,88 & 16,14 & 1,63 & 19,72 & 3,58 \\
\hline Colômbia & 0,57 & 10,41 & 0,80 & 9,72 & $-0,70$ \\
\hline Honduras & 0,15 & 2,72 & 0,40 & 4,86 & 2,14 \\
\hline Indoné sia & 0,33 & 6,09 & 0,37 & 4,46 & $-1,63$ \\
\hline Índia & 0,23 & 4,15 & 0,33 & 4,02 & $-0,13$ \\
\hline Ug anda & 0,18 & 3,21 & 0,28 & 3,34 & 0,12 \\
\hline Perv & 0,16 & 2,93 & 0,26 & 3,09 & 0,16 \\
\hline Etiópia & 0,09 & 1,56 & 0,24 & 2,89 & 1,32 \\
\hline Guatemala & 0,26 & 4,86 & 0,20 & 2,47 & $-2,39$ \\
\hline $\mathrm{R}$ esto do $\mathrm{M}$ undo & 1,43 & 26,26 & 1,38 & 16,65 & $-9,61$ \\
\hline Total & 5,45 & 100,00 & 8,28 & 100,00 & - \\
\hline
\end{tabular}

Fonte: Elaborado pelos autores a partir de USDA (2019)

Nota: Ranking relacionado ao ano de 2018

O comércio mundial de café é dominado em grande parte pelo Brasil, que, na safra de $2018 / 2019$, teve uma participação de $28,80 \%$ no total exportado, seguido por Vietnã $(19,72 \%)$, Colômbia (9,72\%), Honduras (4,86\%), Indonésia (4,46\%), Índia (4,02\%), Uganda $(3,34 \%)$, Peru (3,09\%), Etiópia (2,89\%) e Guatemala (2,47\%). Neste cenário, a Guatemala foi o país que mais reduziu sua participação de mercado em 2,39\%, correspondendo a um declínio na

DRd - Desenvolvimento Regional em debate (ISSNe 2237-9029) 
exportação de $23,07 \%$, que passou de 0,26 milhões de toneladas na safra de 2000/2001 a 0,20 milhões de toneladas na safra de 2018/2019, sendo a quebra de safra de 2012, os altos custos de produção, e os baixos preços internacionais do café os responsáveis pela queda no comércio exterior do país (USDA, 2018).

Em relação à disponibilidade de café brasileiro, na safra 2018/2019, foi de 4,01 milhões de toneladas, e, destes, 59,48\% foram destinados à exportação, 34,74\%, ao consumo interno e $5,79 \%$ foram os estoques finais (USDA, 2019a). Percebe-se que a alta participação da exportação está relacionada à orientação da indústria cafeeira ao mercado externo.

Além disso, a produção brasileira de café é distribuída pelas regiões do país, tomando como base a safra de 2019, da seguinte forma: 3,48\% Norte, 5,40\% Nordeste, $0,83 \%$ CentroOeste, $88,22 \%$ Sudeste e 2,07\% Sul de acordo com a Companhia Nacional de Abastecimento (CONAB, 2019). Com base neste levantamento, percebe-se a alta concentração do café produzido pelo país na Região Sudeste.

A Figura 2 ilustra a produção e a produtividade do café no Brasil, entre os anos de 2000 a 2017.

Figura 2 - Evolução da produção e da produtividade do café verde no Brasil, entre 2000 e 2017

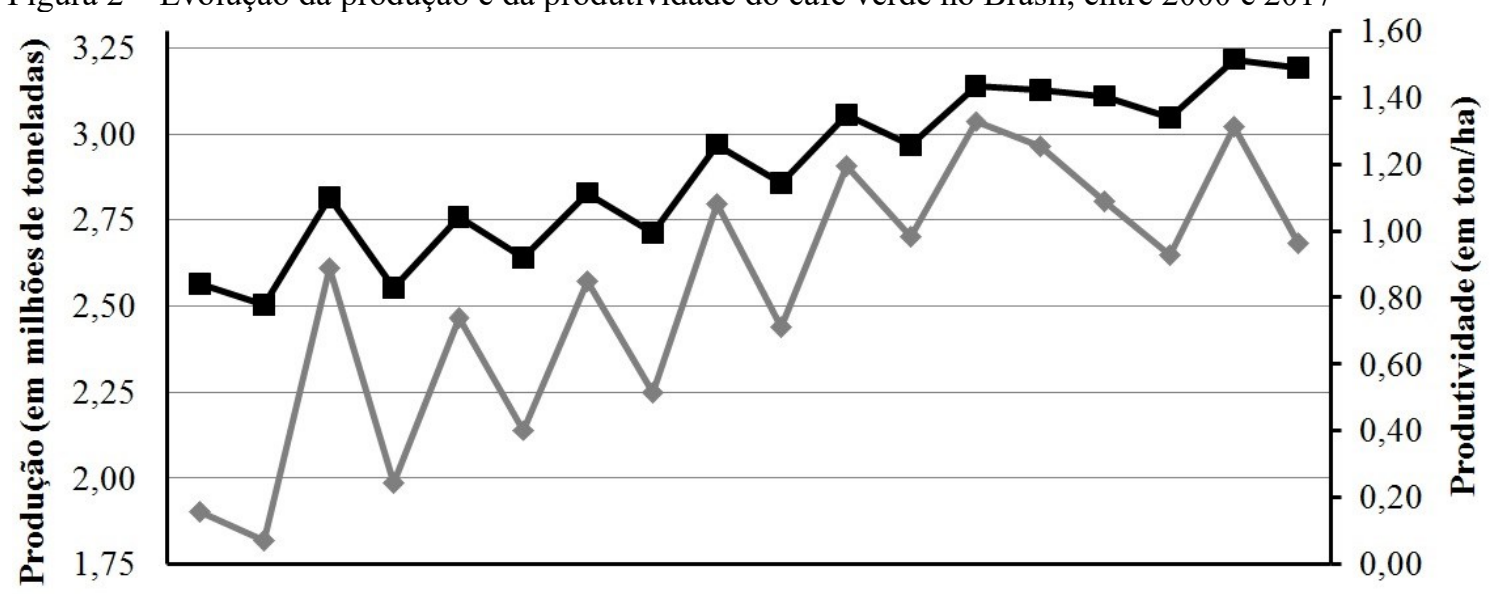

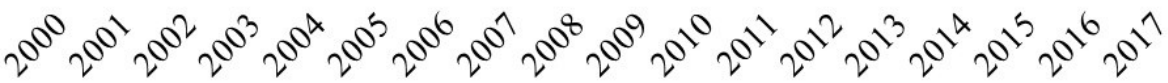

Fonte: Elaborado pelos autores a partir de FAO (2019)

A partir da análise da Figura 2, é possível observar que, apesar da oscilação da série, o crescimento da produtividade do café brasileiro é constante desde o início do período analisado. De acordo com a Conab (2017), o incremento produtivo do café brasileiro está ligado à aplicação de novas tecnologias nessa cultura, com o uso de novas variedades, adubação adequada, irrigação, entre outros. Acrescente-se ainda que a média da produtividade brasileira no período foi de 1,18 ton/ha, bem acima da média mundial de 0,78 ton/ha (FAO, 2019), demonstrando o bom desenvolvimento tecnológico nesta etapa produtiva.

A Figura 3 ilustra a importação, a exportação e o saldo comercial de café verde no Brasil, entre as safras de 2000/2001 e 2018/2019. 
Figura 3 - Evolução da importação, exportação e saldo comercial do café verde no Brasil, entre as safras de $2000 / 2001$ e $2018 / 2019$

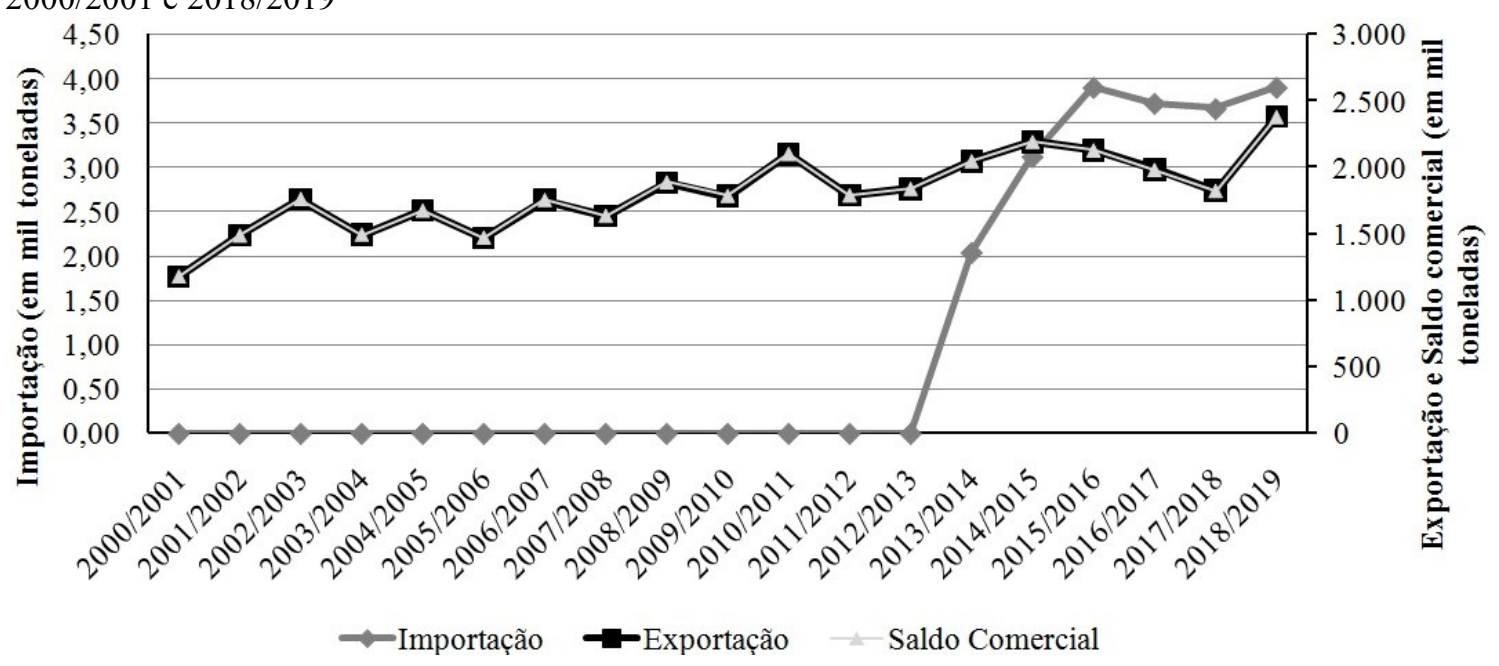

Fonte: Elaborado pelos autores a partir de USDA (2019a)

Percebe-se, assim como no caso da produção e da produtividade, uma linha de tendência crescente nas exportações brasileiras de café, com um crescimento de $102 \%$ entre as safras de 2000/2001 e 2018/2019 (USDA, 2019a). Neste mesmo período, as importações apresentam-se pouco significativas dadas as proporções.

A Figura 4 ilustra a produção e a produtividade do café verde na Colômbia, entre os anos de 2000 e 2017.

Figura 4 - Evolução da produção e da produtividade do café verde na Colômbia entre 2000 e 2017

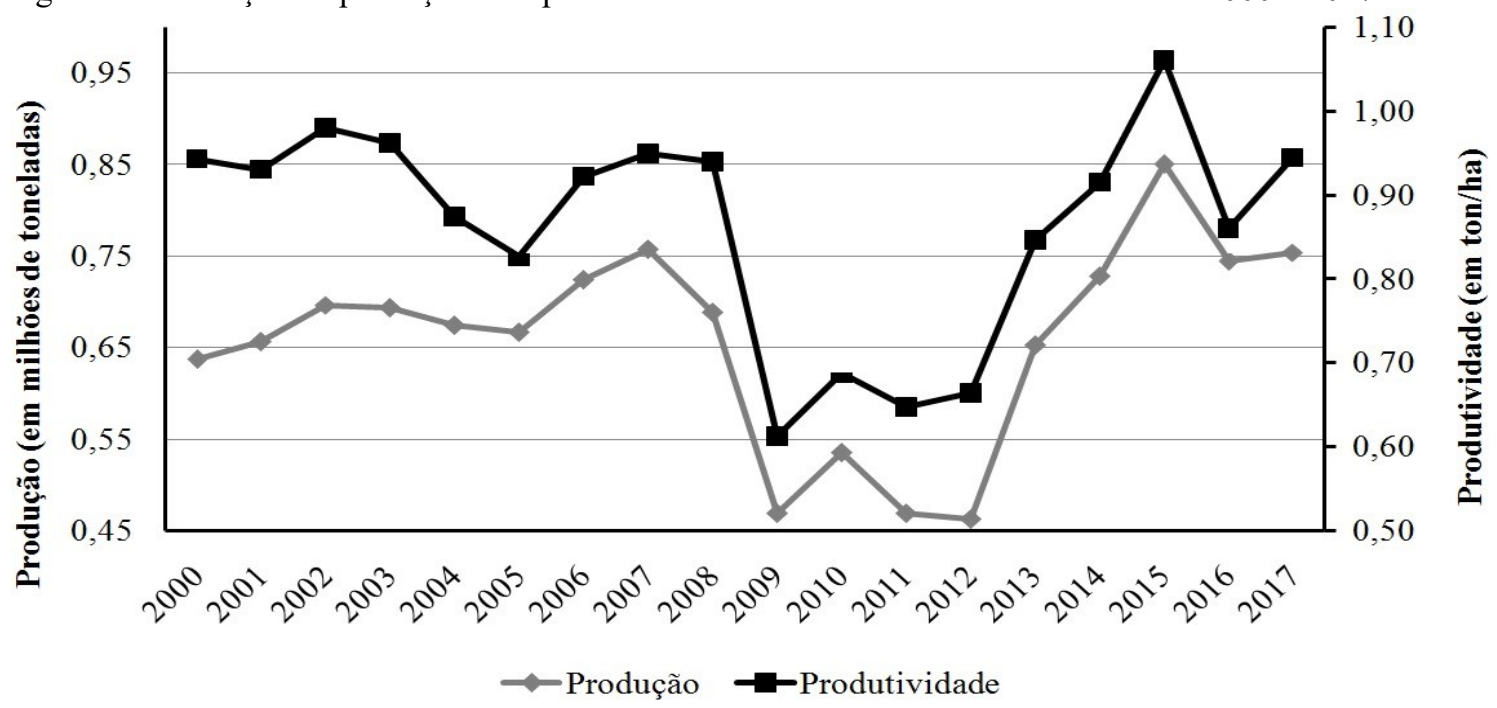

Fonte: Elaborado pelos autores a partir de FAO (2019)

Pela análise da Figura 4, percebe-se a forte oscilação da produtividade do café na Colômbia, que, no ano de 2000, era de 0,94 ton/ha, em 2009 passou a 0,61 ton/ha, e, no ano de 2015 atingiu 1,06 ton/ha, com uma média de 0,87 ton/ha. A produção também apresentou oscilação, iniciando o período com 0,64 milhões de toneladas em 2000, com mínimo de 0,46 milhões de toneladas em 2012, e um máximo de 0,85 milhões de toneladas em 2015 (FAO,

DRd - Desenvolvimento Regional em debate (ISSNe 2237-9029) 
2018), fatos ligados à crise da safra 2007/2008 do café colombiano afetado pelas condições climáticas desfavoráveis do fenômeno La Niña, que facilitou a propagação de pragas como a ferrugem e a broca-do-café (USDA, 2013).

Segundo o USDA (2019a), o total disponível na Colômbia, na safra 2018/2019, foi de 0,97 milhões de toneladas, e, destes, $82,53 \%$ foram destinados à exportação, $12,23 \%$ ao consumo interno e 5,24\% foram os estoques finais. Percebe-se que a indústria cafeeira colombiana, tal como a brasileira, é orientada ao mercado externo.

Com base na Figura 5, identifica-se a evolução das importações, das exportações e o saldo comercial do café verde da Colômbia. As exportações tiveram um incremento de $42 \%$, passando de 568 mil de toneladas, na safra 2000/2001, para 804 mil toneladas na safra de 2018/2019. Este crescimento está relacionado ao incremento da produção, através do programa governamental de renovação dos cafeeiros mais resistentes a pragas e às condições edafoclimáticas do país (USDA, 2017). Já as importações serviram para abastecer o mercado interno, pois a produção foi destinada ao comércio exterior (USDA, 2012; 2017).

Figura 5 - Evolução da importação, exportação e saldo comercial do café verde na Colômbia, entre as safras de $2000 / 2001$ e $2018 / 2019$

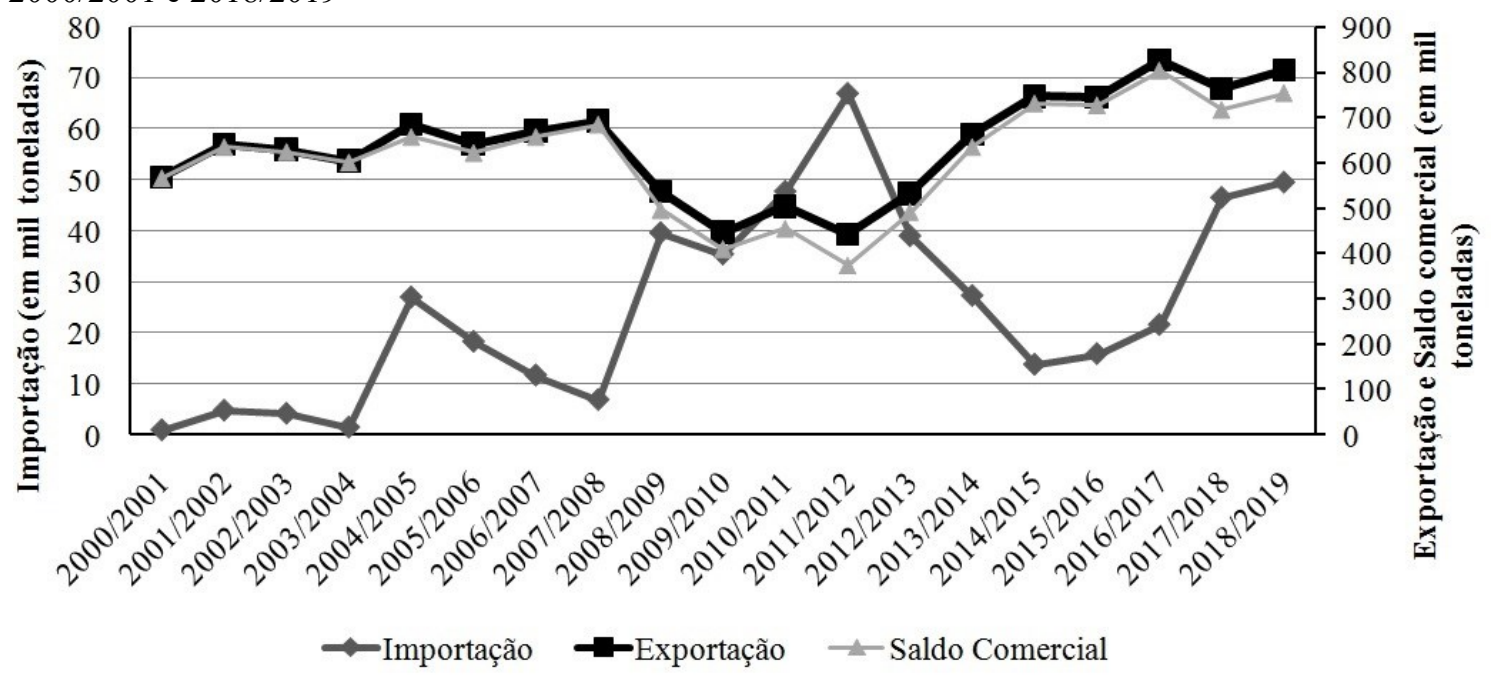

Fonte: Elaborado pelos autores a partir de USDA (2019a)

Por fim, na Tabela 3, é apresentada uma síntese dos principais fatores de competitividade do café entre Brasil e Colômbia, nas safras de 2000/2001 e 2018/2019.

Tabela 3 - Síntese dos principais fatores de competitividade do café verde entre Brasil e Colômbia, nas safras de $2000 / 2001$ e $2018 / 2019$

\begin{tabular}{c|ccc|c|c|c|c|c|c}
\hline \multirow{2}{*}{ Paises } & \multicolumn{3}{|c|}{ Produção (milhões de toneladas) } & \multicolumn{3}{c}{ Exportação (milhões de toneladas) } \\
\cline { 2 - 9 } & $2000 / 2001$ & $\%$ & $2018 / 2019$ & $\%$ & $2000 / 2001$ & $\%$ & $2018 / 2019$ & $\%$ \\
\hline Brasil & 2,05 & 29,09 & 3,89 & 37,13 & 1,18 & 21,66 & 2,38 & 28,80 \\
Colómbia & 0,63 & 8,96 & 0,86 & 8,19 & 0,57 & 10,41 & 0,80 & 9,72 \\
Demais paises & 4,36 & 61,95 & 5,72 & 54,67 & 3,70 & 67,93 & 5,09 & 61,49 \\
Mundo & 7,03 & 100,00 & 10,47 & 100,00 & 5,45 & 100,00 & 8,28 & 100,00 \\
\hline
\end{tabular}

Fonte: Elaborado pelos autores a partir de FAO (2018)

DRd - Desenvolvimento Regional em debate (ISSNe 2237-9029) 
Por meio das análises realizadas, observou-se que tanto o Brasil como a Colômbia apresentaram resultados significativos na produção e na produtividade, dadas as proporções, ao longo dos últimos anos. Contudo, apesar de ambos os países apresentarem crescimento na produtividade, o Brasil ainda obteve maior média na produtividade $(1,18$ ton/ha), já que a Colômbia apresentou ( 0,87 ton/ha), indicando maior competitividade.

Brasil e Colômbia possuem outra semelhança: o fato de registrarem níveis de exportação muito superiores aos de importação sugere que os países têm competitividade no mercado internacional do café. Ainda, ambos os países aumentaram o volume exportado no período, indicando expansão e incremento no setor.

\section{MATERIAL E MÉTODOS}

\subsection{ASPECTOS METODOLÓGICOS}

\subsection{1 Índices de Vantagem Comparativa Revelada (IVCR) e Vantagem Comparativa Revelada Simétrica (VCRS)}

O Índice de Vantagem Comparativa Revelada foi desenvolvido por Balassa (1965), utilizando como base a teoria de Ricardo (1817) como forma de avaliar a competitividade de um país, já que, para o autor, seria inviável avaliar todos os fatores que afetam o desempenho econômico frente aos concorrentes. Além disso, para o autor, esta avaliação deveria recair somente sobre as exportações, já que as importações são influenciadas por barreiras protecionistas. Assim, o IVCR é calculado da seguinte forma:

$$
I V C R=\frac{\frac{x_{i j}}{x_{i}}}{\frac{x_{m j}}{x_{m}}}
$$

em que: $X_{i j}$ representa o total das exportação do país $i$ do produto $j ; X_{i}$ refere-se ao valor total das exportações do país $i$; $X_{m j}$ significa o valor total das exportações mundiais do produto $j$; $X_{m}$ mostra o valor total das exportações mundiais.

O índice deve ser avaliado como segue: quando o resultado for superior à unidade, conclui-se que o país possui vantagem comparativa revelada para as exportações de determinado produto. Por outro lado, quando o resultado for menor do que um, o país não possui vantagem comparativa revelada nas exportações de um produto. Além disso, quanto maior for o índice, maior será a vantagem comparativa do país. O IVCR informa o nível das exportações de um país, com relação à sua pauta exportadora, podendo comparar determinado bem entre diferentes países e permitindo revelar o grau de competitividade do país em questão. 
A fim de melhor analisar as vantagens comparativas entre mais de um competidor e mais períodos, optou-se por utilizar o Índice de Vantagens Comparativas efetuando a normalização, conforme proposto por Laursen (1998):

$$
V C R S=\frac{I V C R-1}{I V C R+1}
$$

Em que o índice representa a Vantagem Comparativa Revelada Simétrica (VCRS). Assim, o valor do índice passa a variar entre -1 e 1 . Se o índice se encontrar entre -1 e 0 , a economia do estado não possui vantagem comparativa revelada naquele determinado produto; entre 0 e 1, a economia possui vantagem comparativa revelada e, quanto mais próximo de 1 , maior será a vantagem.

\subsubsection{Razão de Concentração (CR)}

No presente estudo, foram selecionados os três principais parceiros comerciais de cada país (no caso, CR3), para o café verde, em 2000 e em 2018, a fim de identificar o grau de concentração da comercialização no mercado internacional, conforme resultados descritos na seção 4.2 .

Para o Brasil, em 2000, os países selecionados foram Alemanha, Estados Unidos e Itália. O total das exportações brasileiras de café verde destinadas a estes países e as representatividades sobre o total de café verde exportado pelo Brasil, em 2000, foram, respectivamente, de US\$268,02 milhões (17,19\%) para a Alemanha; US\$218,35 milhões para os Estados Unidos (14,00\%); e US\$ 173,90 milhões para a Itália (11,15\%) (UN COMTRADE, 2019).

Em 2018, para o Brasil, os países selecionados foram Estados Unidos, Alemanha e Itália. O total das exportações brasileiras de café verde e representatividades sobre o total de café verde exportado pelo Brasil em 2018, foram, respectivamente, de US\$ 772 milhões $(17,71 \%)$ para os Estados Unidos; US\$ 749 milhões para a Alemanha $(17,19 \%)$ e US\$ 462 milhões para a Itália (10,59\%) (UN COMTRADE, 2019).

Para a Colômbia, em 2000, os países selecionados foram Estados Unidos, Alemanha e Japão. O total das exportações colombianas de café verde destinadas a esses países e as representatividades sobre o total de café verde exportado pela Colômbia em 2000, foram, respectivamente, de US\$ 359,19 milhões (33,65\%) para os Estados Unidos; US\$ 201,74 milhões para a Alemanha (18,90\%); e US\$ 159,60 milhões para o Japão (14,95\%) (UN COMTRADE, 2019).

Em 2018, para a Colômbia, os países selecionados foram Estados Unidos, Japão e Alemanha. O total das exportações colombianas de café verde e representatividades sobre o total de café verde exportado pela Colômbia em 2018, foram, respectivamente, de US\$1,00 bilhão (44,46\%) para os Estados Unidos; US\$ 195 milhões para o Japão $(8,61 \%)$; e US\$ 181 milhões para a Alemanha (7,99\%) (UN COMTRADE, 2019). 
O somatório das parcelas de mercado das k-ésimas maiores empresas ou países define o grau de concentração, sendo apresentado na Fórmula (3):

$$
C R_{k}=\sum_{i=1}^{k} S i
$$

$\mathrm{Na}$ fórmula, Si representa a parcela de mercado do i-ésimo país, enquanto $k$ significa o número de países pesquisados. Quanto mais alto o valor, mais concentrado é o fluxo comercial das $k$ maiores nações.

\subsection{3 Índice de Orientação Regional (IOR)}

O IOR foi proposto por Yeats (1997) e visa mensurar o peso de um setor/produto nas exportações bilaterais em relação ao peso de suas exportações totais com destino ao resto do mundo. Varia de zero até o infinito. Valores maiores que 1 indicam orientação favorável ao comércio bilateral; o IOR igual a 1 sugere que não há preferência de destino para a exportação, ou seja, o produto não possui orientação de comércio. Valores crescentes do IOR ao longo do tempo indicam tendência para exportar mais para determinado país. Assim, o IOR é calculado da seguinte forma:

$$
I O R=\frac{\frac{X_{k i j}}{X_{i j}}}{\frac{X_{k i e j}}{X_{i e j}}}
$$

em que: Xkij representa as exportações da commodity $k$ do país $i$ para o país $j$; Xij refere-se ao total das exportações do país $i$ para o país $j$; Xkiej significa as exportações da commodity $k$ de $i$ para extra $j$; e Xiej mostra o total das exportações do país $i$ para extra $j$.

\subsection{FONTES DOS DADOS}

$\mathrm{Na}$ análise do mercado mundial do café verde e, especialmente, do panorama brasileiro e colombiano, o presente estudo utilizou a base de dados do FAO (Food and Agriculture Organization of the United Nations) e do USDA (United States Department of Agriculture). Para os principais produtores e exportadores mundiais e, especialmente, o Brasil e a Colômbia, em 2000 e 2018, foram analisadas as variáveis produção (em milhões de toneladas), importação (em mil toneladas), exportação (em milhões de toneladas na Tabela 2, e em mil toneladas nas Figuras 3 e 5), e produtividade (em ton/ha), bem como medidas as participações de cada país, em relação à produção e à exportação, no total mundial. 
Para os cálculos do VCRS, da CR, e do IOR, foram empregados os dados disponíveis no UN COMTRADE (United Nations Comtrade), na FAO (Food and Agriculture Organization of the United Nations) e na WTO (World Trade Organization).

\section{ANÁLISE E DISCUSSÃo DOS RESULTADOS}

4.1 Vantagens comparativas reveladas e competitividade das exportações do café

A Figura 6 especifica os dados do VCRS do Brasil e da Colômbia de 2000 a 2018. Durante todo o período, os dois países apresentaram vantagem comparativa revelada simétrica, com índices entre zero e 1 (um). Além disso, percebe-se o comportamento declinante do índice na Colômbia até o ano de 2012 e a posterior recuperação, reflexo da crise de produção derivada dos fenômenos climáticos e as pragas (USDA, 2017). Ainda, a Colômbia foi a mais competitiva durante todo o período, apresentando índices superiores ao mercado brasileiro.

Figura 6 - Índice de Vantagem Comparativa Revelada Simétrica do café verde do Brasil e da Colômbia de 2000 a 2018

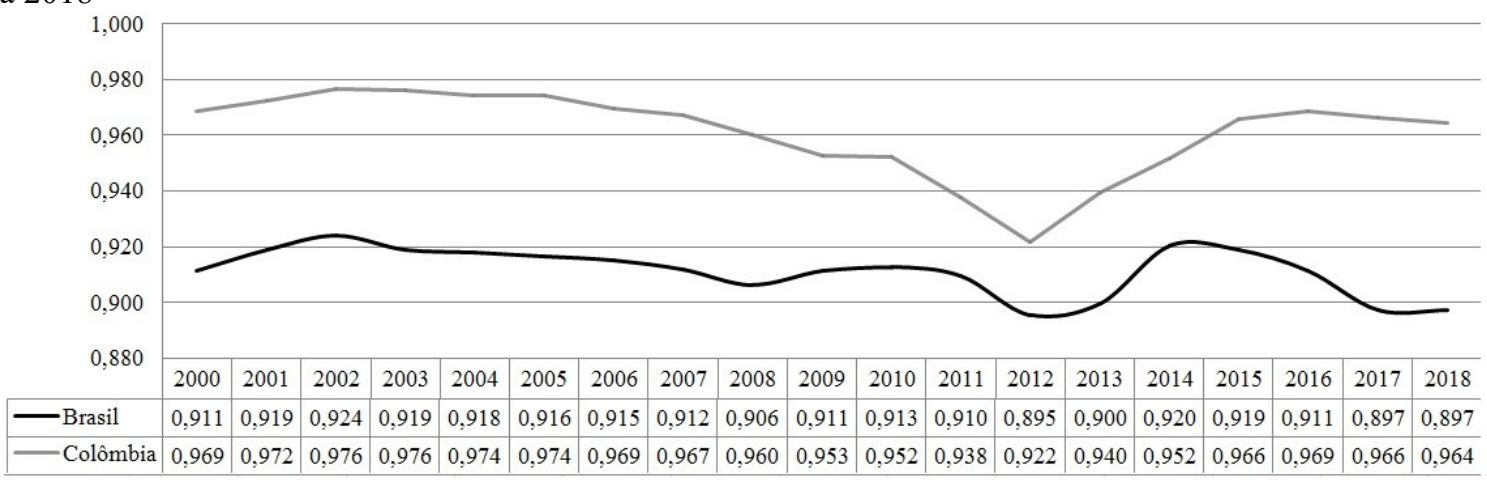

Fonte: Elaborado pelos autores a partir de FAO (2019) e WTO (2019)

A presente pesquisa demonstrou estar em consonância com alguns trabalhos já realizados sobre a competitividade do café brasileiro. Para Sereia, Camara e Anhesini (2012), que também utilizaram o VCRS como indicador, as exportações de café do Brasil se apresentaram competitivas entre os anos de 1990 a 2007, com índice variando entre 0,89 a 0,93. Segundo Thomé \& Ferreira (2015), as exportações brasileiras de café foram competitivas entre os anos de 2003 a 2012. Outro estudo, como o de Franck et al. (2016), apresentaram como resultado competitividade na exportação de café entre 1999 e 2014. Já para Arevalo, Arruda e Carvalho (2016), o Brasil foi competitivo nas exportações de café verde entre os anos de 1994 a 2013.

DRd - Desenvolvimento Regional em debate (ISSNe 2237-9029) 


\subsection{GRAU DE CONCENTRAÇÃO E ÍNDICE DE ORIENTAÇÃO REGIONAL DAS EXPORTAÇÕES DO CAFÉ VERDE}

4.2.1 Grau de concentração e Índice de Orientação Regional das exportações de café verde do Brasil

$\mathrm{Na}$ Tabela 4, são apresentados os graus de participação individual e em conjunto (CR3) dos principais países de destino das exportações do café verde do Brasil para os anos de 2000 e 2018. Os resultados indicaram aumento na concentração das exportações no período analisado. A possível razão desta elevação está ligada ao incremento da parceria comercial, com elevação na participação de mercado, com os Estados Unidos, de $14,00 \%$ a 17,71\% (UN CONTRADE, 2019).

Tabela 4 - CR3 das exportações de café verde do Brasil para os anos de 2000 e 2018

\begin{tabular}{|c|c|c|c|c|}
\hline \multirow{2}{*}{ Produtos/Anos } & \multicolumn{2}{|c|}{2000} & \multicolumn{2}{|c|}{2018} \\
\hline & $P$ aíses & $\%$ & $P$ aíses & $\%$ \\
\hline \multirow{3}{*}{ Café verde } & Alemanha & 17,19 & Estados Unidos & 17,71 \\
\hline & Estados Unidos & 14,00 & Alemanha & 17,19 \\
\hline & Itália & 11,15 & Itália & 10,59 \\
\hline
\end{tabular}

Fonte: Elaborado pelos autores a partir de UN COMTRADE (2019).

Pela análise da Figura 7, identifica-se orientação das exportações brasileiras de café verde (IOR) aos países que foram seus principais destinos em 2000 e 2018. Somente as exportações para os Estados Unidos, no período de 2000 a 2005, não apresentaram a orientação de mercado; o período de 2006 a 2018 e exportações para Alemanha e Itália, de 2000 a 2018, apresentaram a orientação de mercado, com IOR superior à unidade.

Figura 7 - Índice de Orientação Regional (IOR) das exportações brasileiras de café verde para Alemanha, Estados Unidos e Itália, em US\$
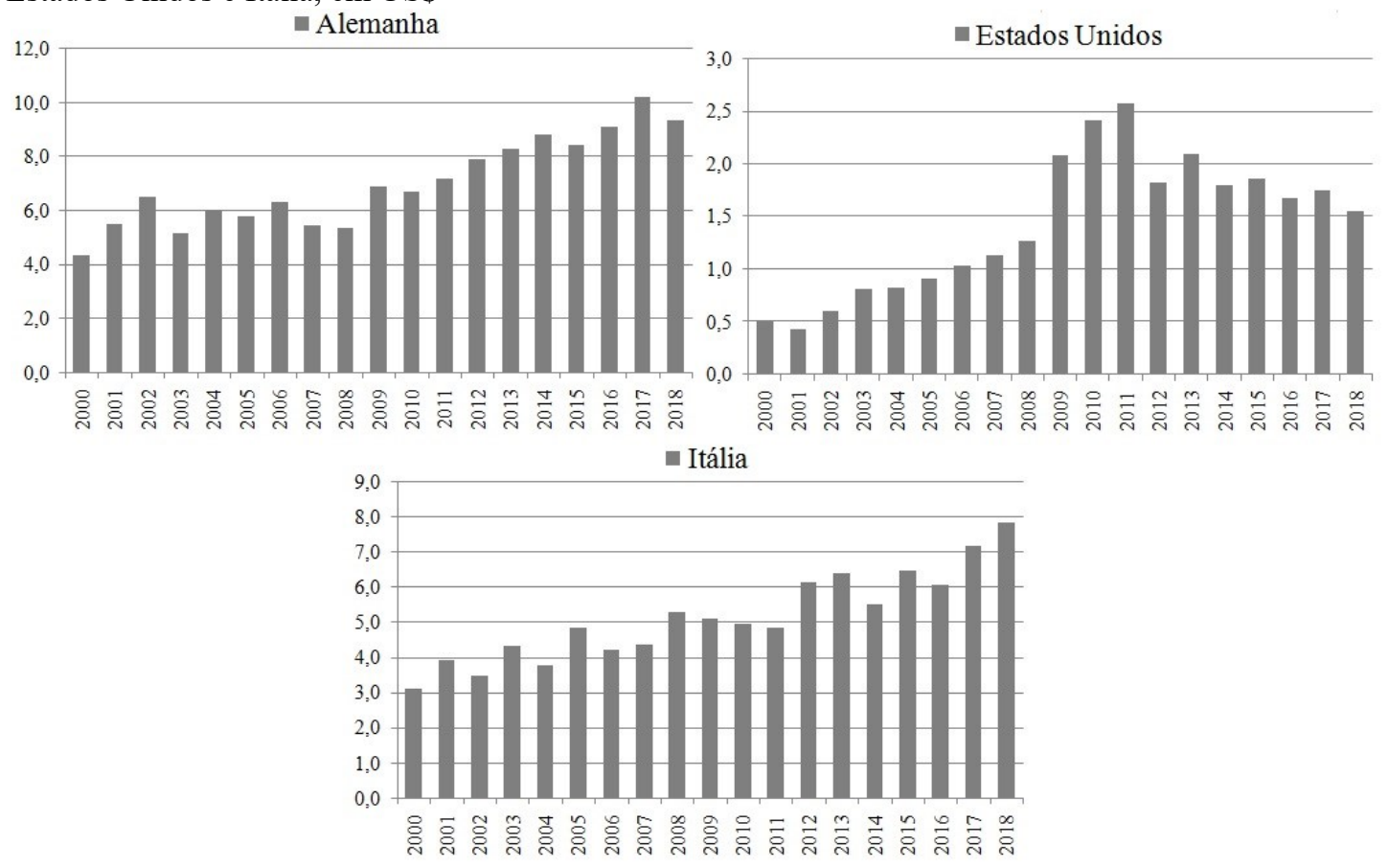

Fonte: Elaborado pelos autores a partir de UN COMTRADE (2019)

DRd - Desenvolvimento Regional em debate (ISSNe 2237-9029) 
Ainda, na Figura 7, verifica-se a evolução do IOR, demonstrando a tendência das exportações brasileiras do café verde aos países parceiros.

As exportações brasileiras do café verde para a Alemanha foram crescentes, passando de US\$ 268,20 milhões, em 2000, a US\$ 749 milhões em 2018 (UN COMTRADE, 2019), refletindo, desta forma, as elevações consecutivas do IOR, que passou de 4,32 a 9,34. Destacase que o país é um importante parceiro comercial brasileiro, assumindo a $4^{\mathrm{a}}$ e $6^{\mathrm{a}}$ posição, respectivamente, em 2000 e em 2018, entre países para os quais o Brasil mais exportou, sendo os principais produtos o minério de ferro, o café e a soja (BRASIL, 2019).

A tendência das exportações brasileiras aos Estados Unidos foi de crescimento, visto que, em 2000, eram de US\$ 13,39 bilhões, e, em 2018, foram de US\$ 28,70 bilhões, com um aumento de 114\%. Ainda nesta perspectiva, houve incremento das importações norteamericanas de café verde do Brasil, que, em 2000, eram de US\$218,35 milhões, e, em 2018, foram de US\$ 772 milhões (UN COMTRADE, 2019), com um aumento de 254\%, evidenciado nos valores crescentes do IOR no período, que passou de 0,51 em 2000, a 1,55 em 2018. Ainda, os Estados Unidos apresentam importante parceria comercial com o Brasil, assumindo a $2^{\mathrm{a}}$ posição, em 2000 e em 2018, de países que o Brasil mais exportou, sendo os principais produtos aviões, calçados e produtos semimanufaturados de ferro (BRASIL, 2019).

Em relação à Itália, as importações de café verde do Brasil representaram uma média de $36,31 \%$, de 2000 a 2018 , em relação ao total da importação do produto, caracterizando o país brasileiro como o maior fornecedor da commodity no período, seguido por Vietnã e Índia, com as médias de participações, respectivamente, de 12,49\% e 10,84\% (UN COMTRADE, 2019). Além disso, os valores do IOR das exportações brasileiras de café verde para a Itália foram crescentes, passando de 3,10, em 2000, a 7,86 em 2018, indicando fortalecimento do comércio e tendência a exportar mais.

4.2.2 Grau de concentração e Índice de Orientação Regional das exportações de café verde da Colômbia

Pela análise da Tabela 5, percebe-se uma redução da concentração das exportações de café verde da Colômbia, de 2000 a 2018 , passando de $67,51 \%$ para $61,05 \%$, o que indica aumento na dispersão das exportações. A origem da mudança nas importações dos principais parceiros colombianos, como o caso do Japão, é que esse país teve sua parceria comercial fortalecida com o Brasil, com aumento de $10 \%$ na participação das importações brasileira de café que, em 2000, eram de US\$178,19 milhões (representando 23\% das importações japonesas de café verde) e, em 2018, passaram a US\$ 321 milhões (representando $28 \%$ das importações japonesas de café verde). Já a Alemanha, em 2018, teve parcerias comerciais fortalecidas com Brasil, Vietnã e Honduras, que, somados, representaram 59\% do total de café verde importado pelo país alemão (UN COMTRADE, 2019). 
Tabela 5 - CR3 das exportações de café verde da Colômbia para os anos de 2000 e 2018

\begin{tabular}{|c|c|c|c|c|}
\hline \multirow{2}{*}{$\begin{array}{c}\text { Produtos/ } \\
\text { Anos }\end{array}$} & \multicolumn{2}{|c|}{2000} & \multicolumn{2}{|c|}{2018} \\
\hline & Países & $\%$ & $P$ aíses & $\%$ \\
\hline & Estados Unidos & 33,65 & Estados Unidos & 44,46 \\
\hline Café verde & Alemanha & 18,90 & Japão & 8,61 \\
\hline & Ja pão & 14,95 & A lemanha & 7,99 \\
\hline CR 3 & & & & \\
\hline
\end{tabular}

Fonte: Elaborado pelos autores a partir de UN COMTRADE (2019)

Na Figura 8, verifica-se a evolução do IOR, demonstrando a tendência das exportações colombianas do café verde aos países parceiros.

Figura 8 - Índice de Orientação Regional (IOR) das exportações colombianas de café verde para os Estados Unidos, o Japão e a Alemanha, em US\$
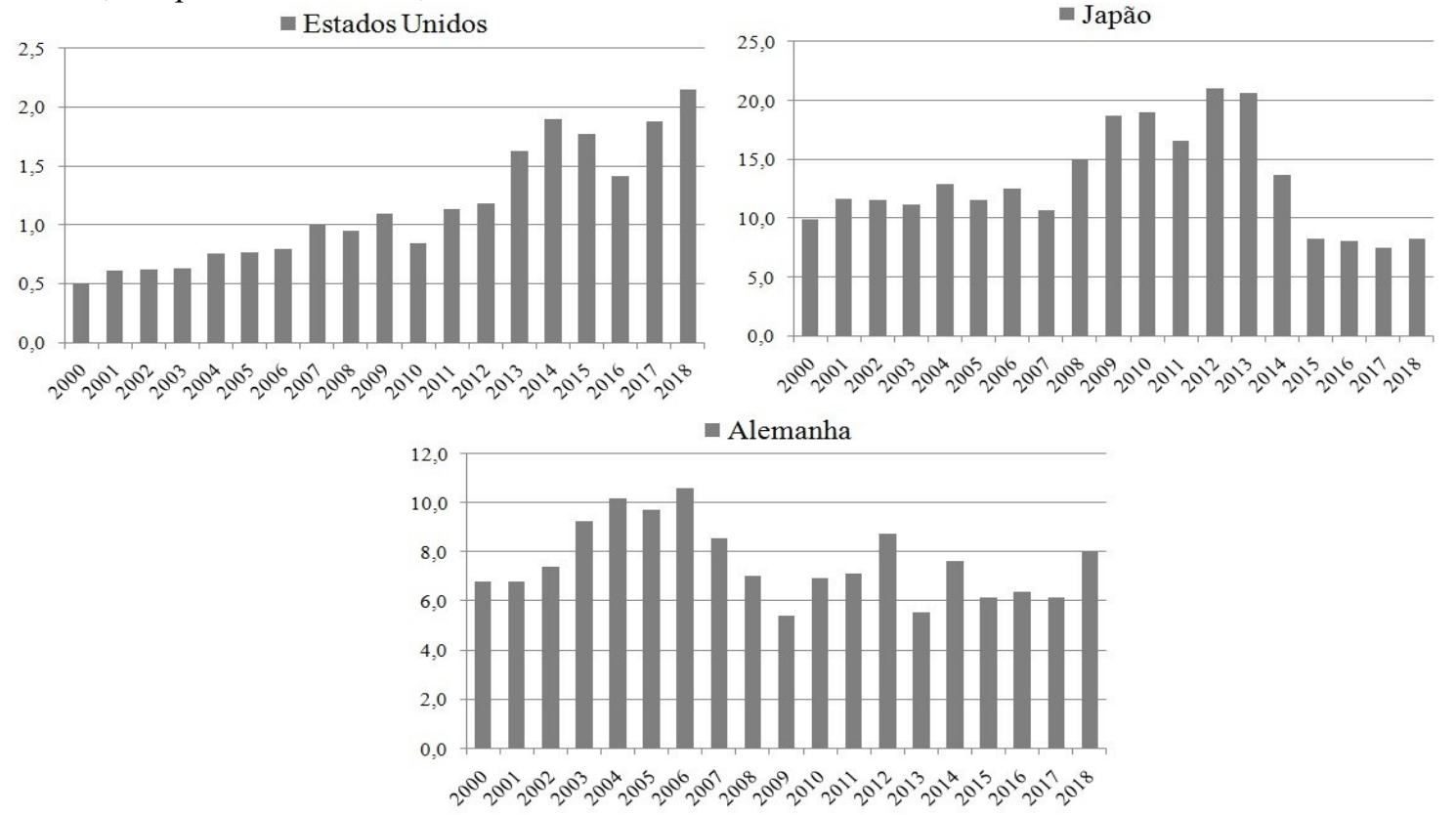

Fonte: Elaborado pelos autores a partir de UN COMTRADE (2019)

Segundo os dados do UN CONTRADE (2019), de 2000 a 2018, foi significativa a participação dos Estados Unidos sobre o total de café exportado pela Colômbia, com uma média de 38,47\%, refletindo um IOR superior à unidade nos anos de 2007, 2009, e de 2011 a 2018, indicando orientação de mercado nestes anos. É interessante destacar também que as exportações colombianas totais ao país norte-americano, extracafé, cresceram $63,81 \%$, pois, em 2000 , eram de US\$ 6,3 bilhões, e, em 2018, passaram a US\$10,32 bilhões, refletindo a parceria comercial, especialmente em produtos como petróleo e carvão (INTERNATIONAL TRADE CENTRE - ITC, 2019a).

A participação das exportações colombianas de café verde sobre o total das exportações para o Japão foi decrescente, pois, em 2000, representavam 69,26\%, e em 2018 passaram a representar 41,16\%, refletindo, desta forma, apesar da oscilação, as reduções do IOR, que passou de 9,86 a 8,21 . Por outro lado, as exportações colombianas totais ao país japonês tiveram um crescimento de $106 \%$, pois, em 2000, eram de US\$230,43 milhões, e, em 2018, passaram a US\$ 474,06 milhões, com principais produtos exportados o café, petróleo e carvão (ITC, 2019b).

DRd - Desenvolvimento Regional em debate (ISSNe 2237-9029) 
A tendência do IOR das exportações colombianas de café verde para a Alemanha, apesar da oscilação, foi de crescimento, uma vez que, em 2000, era de 6,83, e, em 2018, passou a 8,00. Dentre os principais produtos de exportação da Colômbia para a Alemanha estão café, petróleo e frutas (ITC, 2019c).

\section{CONSIDERAÇÕES FINAIS}

O objetivo deste estudo foi o de analisar a competitividade das exportações brasileiras no mercado mundial do café verde, entre 2000 a 2018, em comparação ao terceiro maior produtor e exportador mundial, a Colômbia. Além disso, analisaram-se o grau de concentração e a orientação de mercado das exportações desses países. Os resultados obtidos sobre a participação no comércio internacional para os países, analisando as safras de 2000/2001 e 2018/2019, indicaram tendências opostas na produção, com crescimento do Brasil, passando de $29,09 \%$ a 37,13\%, e redução na Colômbia, 8,96\% a 8,19\%; e na exportação, o Brasil passando de $21,66 \%$ a $28,80 \%$, e a Colômbia passando de $10,41 \%$ a $9,72 \%$.

Sobre a produtividade do café, o Brasil apresentou-se como o mais produtivo, com uma média de 1,18 ton/ha em relação à Colômbia, que apresentou uma média de 0,87 ton/ha, sendo mais competitivo neste quesito. Além disso, ambos os países apresentaram média acima da média mundial de 0,78 ton/ha, demonstrando bons desenvolvimentos tecnológicos nesta etapa do processo produtivo.

Em relação à competitividade, os VCRS observados para o Brasil e a Colômbia para o produto café verde foram superiores à unidade, entre 2000 a 2018, comprovando a competitividade internacional dos países. Além disso, a Colômbia foi mais competitiva no período, com índices superiores ao concorrente.

O Brasil apresentou aumento na concentração das exportações do café verde no período analisado, relacionado ao incremento da parceria comercial com os Estados Unidos, que elevaram suas importações. A Colômbia, por outro lado, revelou desconcentração nas exportações do café verde de 2000 a 2018, passando de 67,51\% a 61,05\%, fato atrelado à perda de mercado para Brasil, Vietnã e Honduras.

As exportações brasileiras do café verde apresentaram-se orientadas (IOR) aos três principais parceiros comerciais, nos seguintes anos: Alemanha e Itália, de 2000 a 2018; e para os Estados Unidos, de 2006 a 2018. Já a Colômbia apresentou suas exportações do café verde orientadas, nos seguintes anos, aos países Estados Unidos, 2007, 2009, e de 2011 a 2018; Alemanha e Japão, de 2000 a 2018.

Entre as limitações do presente trabalho está o fato de os índices utilizados serem estáticos, ou seja, permitem a análise em períodos de tempos específicos, não compreendendo diversas alterações econômicas. Neste sentido, fazem-se pertinentes análises com acuidade, utilizando modelos econométricos, bem como de Equilíbrio Geral de Gerações Sobrepostas, os quais permitem captar a evolução das mudanças econômicas e sociais na competitividade setorial.

DRd - Desenvolvimento Regional em debate (ISSNe 2237-9029) 


\section{REFERÊNCIAS}

AREVALO, J. L. S.; ARRUDA, D. O.; CARVALHO, J. P. Competitividade no comércio internacional do café: um estudo comparativo entre Brasil, Colômbia e Peru. Organizações Rurais \& Agroindustriais, Lavras, v. 18, n. 1, p. 62-78, 2016.

BALASSA, B. Trade liberalization and revealed comparative advantage. The Manchester School of Economic and Social Studies, v. 32, p. 99-123, 1965.

BEST, M. H. The New Competition. Institutions of Industrial Restructuring. Harvard University Press, Cambridge, 1990.

BRASIL. Ministério da Indústria, Comércio Exterior e Serviços (MDIC). Balança Comercial. Disponível em: $<\mathrm{http}$ :/www.mdic.gov.br/index.php/comercioexterior/estatisticas-de-comercio-exterior/balanca-comercial-brasileira-acumulado-doano?layout=edit\&id=3056>. Acesso em: 24 set. 2019.

CONAB (Companhia Nacional de Abastecimento). Acompanhamento da safra brasileira. Café. v. 3, safra 2019, n. 3, Terceiro Levantamento, set. 2019. Disponível em:

$<$ https://www.conab.gov.br/component/k2/item/download/28519_1451c80af85a09013032c62 c38317623>. Acesso em: 24 set. 2019.

CONAB (Companhia Nacional de Abastecimento). A cultura do café: análise dos custos de produção e da rentabilidade nos anos-safra 2008 a 2017. Disponível em:

$<$ http://www.agricultura.gov.br/noticias/lavoura-produtiva-foi-o-principal-fator-de-aumentoda-renda-do-produtor-de-cafe/copy_of_ConabAculturadoCafAnlisedosCustosdeProduoeda Rentabilidadenosanossafra2008a2017.pdf>. Acesso em: 17 dez. 2018.

FAO. Food and Agriculture Organization of the United Nations. Disponível em: $<$ http://www.fao.org/faostat/en/\#data $>$. Acesso em: 24 set. 2019.

FRANCK, A. G. S.; SILVA, M. L.; SILVA, R. A.; CORONEL, D. A. Análise da competitividade do mercado exportador brasileiro de café. Desafio Online, Campo Grande, v. 4, n. 3, set./dez. 2016.

GURGEL, A. C. Impactos de políticas comerciais e agrícolas sobre a agropecuária e a agroindústria brasileiras. In: CONGRESSO BRASILEIRO DE ECONOMIA E

SOCIOLOGIA RURAL, 52. 2014, Goiânia. Heterogeneidade e suas implicações no Rural. Anais... Goiânia, 2014.

ITC (International Trade Centre). Bilateral trade between Colombia and United States of America. 2019a. Disponível em: $<$ https:/www.trademap.org/Bilateral_TS.aspx?nvpm= $1 \% 7 \mathrm{c} 170 \% 7 \mathrm{c} \% 7 \mathrm{c} 842 \% 7 \mathrm{c} \% 7 \mathrm{cTOTAL} \% 7 \mathrm{c} \% 7 \mathrm{c} \% 7 \mathrm{c} 2 \% 7 \mathrm{c} 1 \% 7 \mathrm{c} 1 \% 7 \mathrm{c} 2 \% 7 \mathrm{c} 2 \% 7 \mathrm{c} 1 \% 7 \mathrm{c} 1 \% 7 \mathrm{c} 1$ $\% 7 \mathrm{c} 1>$. Acesso em: 24 set. 2019.

DRd - Desenvolvimento Regional em debate (ISSNe 2237-9029) 
ITC (International Trade Centre). Bilateral trade between Colombia and Japan. 2019b. Disponível em: $<$ https://www.trademap.org/Bilateral_TS.aspx?nvpm $=1 \% 7 \mathrm{c} 170 \% 7 \mathrm{c} \%$ $7 \mathrm{c} 392 \% 7 \mathrm{c} \% 7 \mathrm{c} 27 \% 7 \mathrm{c} \% 7 \mathrm{c} \% 7 \mathrm{c} 4 \% 7 \mathrm{c} 1 \% 7 \mathrm{c} 1 \% 7 \mathrm{c} 2 \% 7 \mathrm{c} 2 \% 7 \mathrm{c} 1 \% 7 \mathrm{c} 1 \% 7 \mathrm{c} 1 \% 7 \mathrm{c} 1>$. Acesso em: 24 set. 2019.

ITC (International Trade Centre). Bilateral trade between Colombia and Germany. 2019c. Disponível em: $<$ https://www.trademap.org/Bilateral_TS.aspx?nvpm $=1 \% 7 \mathrm{c} 170 \% 7 \mathrm{c} \%$ 7c276\%7c\%7cTOTAL\%7c\%7c\%7c2\%7c1\%7c1\%7c2\%7c2\%7c1\%7c1\%7c1\%7c1>. Acesso em: 24 set. 2019.

KENNEDY, P.L.; HARRISON, R.W.; PIEDRA, M.A. Analysing Agribusiness Competitiveness: Case of the United States Sugar Industry. International Food and Agribusiness Management Review, v. 1, n. 2, p. 245-257, 1998.

LAURSEN K. Revealed comparative advantage and the alternatives as measures of international specialisation. DRUID Working Paper, p. 98-30, 1998.

NISHIJIMA, M.; SAES, M. S. M.; POSTALI, F. A. S. Análise de Concorrência no Mercado Mundial de Café Verde. Revista de Economia e Sociologia Rural - RESR, Piracicaba, SP, v. 50, n. 1, p. 69-82, jan./mar. 2012.

PORTER, M. Vantagem competitiva das nações. Rio de Janeiro: Campus, 1989.

RICARDO, D. Princípios de economia política e tributação. São Paulo: Nova Cultural, 1996.

SEREIA, V. J.; CAMARA, M. R. G.; ANHESINI, J. A. R. Competitividade do complexo cafeeiro: uma análise a partir do market share e das vantagens comparativas simétricas.

Revista de Economia, Curitiba, v. 38, n. 1, p. 07-34, jan./abr. 2012.

THOMÉ, K. M.; FERREIRA, L. S. Competitividade e estrutura de mercado internacional de café: análise de 2003 a 2012. Coffee Science, Lavras, v. 10, n. 2, p. 184 - 194, abr./jun. 2015.

UN COMTRADE. United Nations Commodity Trade Statistics. Disponível em: $<$ http://comtrade.un.org/>. Acesso em: 23 set. 2019.

USDA (United States Department of Agriculture). Custom Query. 2019a. Disponível em: $<$ https://apps.fas.usda.gov/psdonline/app/index.html\#/app/advQuery>. Acesso em: 03 jan. 2019.

USDA (United States Department of Agriculture). Coffee annual. Mexico. 2019b.

Disponível em: < https://gain.fas.usda.gov/Recent\%20GAIN\%20Publications/

Coffee\%20Annual_Mexico\%20City_Mexico_5-31-2019.pdf>. Acesso em: 24 set. 2019.

USDA (United States Department of Agriculture). Coffee annual. Guatemala. 2018.

Disponível em: <https://gain.fas.usda.gov/Recent\%20GAIN\%20Publications/

Coffee\%20Annual_Guatemala\%20City_Guatemala_5-9-2018.pdf $>$. Acesso em: $14 \mathrm{dez}$. 2018 .

DRd - Desenvolvimento Regional em debate (ISSNe 2237-9029) 
USDA (United States Department of Agriculture). Coffee annual. Colombia. 2012.

Disponível em: < https://gain.fas.usda.gov/Recent\%20GAIN\%20Publications/

Coffee\%20Annual_Bogota_Colombia_5-14-2012.pdf $>$. Acesso em: 18 jun. 2019.

USDA (United States Department of Agriculture). Coffee: World Markets and Trade. June 2013. Disponível em: $<$ https://downloads.usda.library.cornell.edu/usdaesmis/files/m900nt40f/5d86p067g/hq37vp06b/tropprod-06-21-2013.pdf $>$. Acesso em: 18 jun 2019.

USDA (United States Department of Agriculture). Coffee annual. Colombia. 2017.

Disponível em: <https://gain.fas.usda.gov/Recent\%20GAIN\%20Publications/

Coffee\%20Annual_Bogota_Colombia_5-15-2017.pdf>. Acesso em: 18 jun 2019.

VIEIRA FILHO, J. E. R.; FISHLOW, A. Agricultura e indústria no Brasil: inovação e competitividade. Brasília: Ipea, 2017.

WTO (World Trade Organization). World Trade Statistical Review. 2019. Disponível em: $<$ https://www.wto.org/english/res_e/statis_e/wts2019_e/wts2019_e.pdf $>$. Acesso em: 24 set. 2019

WTO. World Trade Organization. 2018. Disponível em: <http://stat.wto.org/ StatisticalProgram/WSDBStatProgramHome.aspx?Language=E $>$. Acesso em: 15 jul. 2018.

WTO (World Trade Organization). Tariff analysis online. Disponível em: $<$ http://tao.wto.org/>. Acesso em: 05 jun. 2019.

YEATS, A. Does Mercosur's trade performance raice concerns about the effects of regional trade arrangements? Washington, D.C.: World Bank, 1997. 